Article

\title{
Ameliorative Effects of Honey, Propolis, Pollen, and Royal Jelly Mixture against Chronic Toxicity of Sumithion Insecticide in White Albino Rats
}

\author{
Atef M.K. Nassar ${ }^{1, *} \mathbb{0}$, Yehia M.M. Salim ${ }^{1}$, Khalid S.A. Eid ${ }^{1}$, Hazem M. Shaheen ${ }^{2}{ }^{\mathbb{D}}$, \\ Abdullah A. Saati ${ }^{3}$, Helal F. Hetta ${ }^{4,5}{ }^{\mathbb{D}}$, Amr Elmistekawy ${ }^{6}$ and Gaber El-Saber Batiha ${ }^{2, * \mathbb{D}}$ \\ 1 Plant Protection Department, Faculty of Agriculture, Damanhour University, Damanhour 22511, AlBeheira, \\ Egypt; yehia.salim@agr.dmu.edu.eg (Y.M.M.S.); khalid.eid@agr.dmu.edu.eg (K.S.A.E.) \\ 2 Department of Pharmacology and Therapeutics, Faculty of Veterinary Medicine, Damanhour University, \\ Damanhour 22511, AlBeheira, Egypt; dr_hazemshaheen3010@yahoo.com \\ 3 Department of Community Medicine \& Pilgrims Healthcare, Faculty of Medicine, Umm Al-Qura University, \\ Makkah 24382, Saudi Arabia; aaasaati@uqu.edu.sa \\ 4 Department of Medical Microbiology and Immunology, Faculty of Medicine, Assiut University, \\ Assiut 71515, Egypt; helal.hetta@uc.edu \\ 5 Departmentof Internal Medicine, University of Cincinnati College of Medicine, Cincinnati, OH 45267, USA \\ 6 Department of Internal Medicine, Gastroenterology Division, Faculty of Medicine, Al-Azhar University, \\ Cairo 11651, Egypt; drmistekawy@azhar.edu.eg \\ * Correspondence: atef.nassar@dmu.edu.eg (A.M.K.N.); dr_gaber_batiha@vetmed.dmu.edu.eg (G.E.-S.B.)
}

Academic Editors: Maria do Carmo Barreto, Laila Moujir Moujir and Nelson Simões Received: 7 May 2020; Accepted: 2 June 2020; Published: 5 June 2020 check for
updates

\begin{abstract}
Sumithion (Fenitrothion) (SUM) is an organophosphorus insecticide used to combat a wide variety of plant pests. Exposure to SUM causes significant toxicity to the brain, liver, kidney, and reproductive organs through, for example, binding to DNA, and it induces DNA damage, which ends with oxidative stress. Therefore, the present study aimed to examine the protective role of bee products: a mixture of honey, propolis, palm pollen, and royal jelly (HPPJ) against SUM-induced toxicity. Twenty-four male albino rats (Rattus norvegicus) were classified into four groups, each containing six rats: control (corn oil), SUM (85 mg/kg; 1/20 LD 50$)$ HPPJ, and SUM + HPPJ once daily for 28 consecutive days. Blood samples were gently collected in sterilized ethylenediaminetetraacetic acid (EDTA) tubes for blood picture analyses and tubes without anticoagulant for serum isolation. Serum was used for assays of enzymatic and biochemical characteristics. The results revealed that SUM increased the weights of the liver, kidney, and brain as well as the enzymatic activity of glutathione peroxidase (GP), serum superoxide dismutase (SOD), and glutathione-S-transferase (GST). Additionally, SUM significantly increased the activity of lactate dehydrogenase (LDH), alkaline phosphatase (ALP), and $\gamma$-glutamyltransferase $(\gamma-\mathrm{GT})$ and glucose, uric acid, and creatinine contents, while decreasing the acetylcholine esterase (AChE) activity and total lipids and total protein content. Furthermore, because of the inclusion of phenolic, flavonoids, terpenoids, and sugars, the HPPJ mixture counteracted the hematological, renal, and hepatic toxicity of SUM exposure.
\end{abstract}

Keywords: sumithion; bee products; hematological; renal; hepatotoxicity; oxidative stress; AChE

\section{Introduction}

The intensification of pesticides exhibits a prompt threat to human health, while the gradual build-up of pesticides in the environment and the human body cause serious toxic effects $[1,2]$. Organophosphorus pesticides (OPs) are readily used worldwide to control public health and agricultural pests [3] and have a significant potential health hazard due to their acute or chronic poisoning [4]. 
Sumithion (SUM, O, O-dimethyl-O-(3-methyl-4-nitrophenyl) phosphorothioate) is a contact-acting-OP insecticide that is used against mites and insects on vegetables, rice, cereals, and cotton [5]. SUM is distinguished by a rapid and severe absorption in the digestive tract and a preferable aggregation in the liver and blood [6]. Previous studies have shown that SUM causes remarkable changes in several organs such as the kidneys, brain, reproductive organs, and liver [5,6]. Additionally, many reports revealed that OPs bind to DNA [7]. In turn, the DNA damage triggers a machinery response like MAPK, NF- $\mathrm{kB}$, and p53 mechanisms that control genes associated with the metabolism of reactive oxygen species (ROS) and $\mathrm{Ca}^{+2}$ apoptosis and homeostasis [8]. Therefore, Vanova et al. [9] hypothesized that OPs' phosphorylate proteins/low molecular antioxidants had a pro-oxidative effect.

Moreover, many experiments have reported that OPs affect many vital organs, such as chronic OP toxicity, which may cause extreme liver cell injury [10]. Endogenous antioxidant status, essential trace elements, and liver enzymes are negatively affected by chronic rat intoxication with OPs [11]. Besides, hematological parameters were considered to be a rapid bioindicator of toxicity after prolonged exposure to OPs including malathion [12]. To lessen the toxicity of pesticides, several approaches were attempted, including the intake of medicinal herbs and/or their natural constituents [13]. Honey as a natural product and bee products (propolis, wax, pollen, royal jelly) have caught researchers' attention as a supplementary and alternate therapy due to their antioxidant properties [14-16]. Moreover, they were used as substances for treating wounds, burns, cancer, cardiovascular, gastrointestinal tract, and neurodegenerative disorders [17-19]. Propolis was reported as having an ameliorative activity against chlorpyrifos and profenofos toxicity by increasing the immune capacity by significantly increasing the immunoglobulins [20]. Honey at a dose of $1.2 \mathrm{~g} / \mathrm{kg}$ increased the activity and amount of antioxidants like vitamin $C, \beta$-carotene, uric acid, and glutathione reductase in healthy people [21].

However, bee products are known as possible sources of natural antioxidants, which can combat oxidative stress because of their phenolic compound (phenolic acids and flavonoids) content that expresses a scavenging activity of free radicals [22]. Additionally, these phenolics, sugars, proteins, carotenes, amino acids, Maillard reaction products, organic acids, and other minor compounds participate in the antioxidant effects of honey and other bee products [23]. The proposed mechanisms include the sequestration of free, superoxide, and hydroxyl radicals, metallic ion chelation, and hydrogen donation [24,25].Therefore, the current research was planned to a) assess the effects of SUM oral administration for 28 successive days on the hematological, renal, hepatic, and oxidative toxicity of male white albino rats, $b$ ) investigate the ameliorative role of a bee products-based mixture (honey, propolis, palm pollen, and royal jelly) against possible SUM toxic effects, and c) discriminate the chemical constituents of the mixture using the gas chromatography-mass spectroscopy (GC-MS) technique.

\section{Materials and Methods}

\subsection{Chemicals and Materials}

Sumithion (O, O-dimethyl-O-(4-nitrophenyl) phosphorothioate, CAS 122-14-5, 99\% purity) was purchased from Supelco Analytical (PA, USA), dissolved in corn oil and stored for future use. 5,5-dithiobis-2-nitrobenzoic acid (DTNB-Ellman's reagent: Sigma order \#D218200), bovine serum albumin (BSA: Sigma order \#A2153-10G), acetylthiocholine iodide (ATChI; Sigma order \#A5751-250MG), and brilliant (Coomassie) blue G-250 (Sigma order \#B0770-5G) were purchased from Sigma-Aldrich through the local agent (AGITECH), Cairo, Egypt. Citrus bee honey and fresh royal jelly were collected from healthy honeybee colonies at an apiary located at Kafr El-Dawar district, El-Beheira Governorate, Egypt. Fresh palm pollen grains were collected from palm trees at Rashid district, El-Beheira Governorate. Refined propolis powder was obtained from the local market and ground into a fine powder. Then, bee products were mixed as a mixture of $22.5 \mathrm{~g}$ of citrus bee honey, $1 \mathrm{~g}$ of refined propolis, $1 \mathrm{~g}$ of palm pollen grains, and $0.5 \mathrm{~g}$ of fresh royal jelly following a very famous medicinal recipe that is extensively used as an antioxidant treatment. 


\subsection{Experimental Animals}

Twenty-four healthy adult male albino rats $(120 \pm 5 \mathrm{~g})$ were kept in an animal room at $25 \pm 2{ }^{\circ} \mathrm{C}$ and in an alternate $12 \mathrm{~h}$ light and dark cycle. Two weeks before the experiment was conducted, the animals were allowed to acclimatize to the testing facility conditions. Afterwards, the rats were caged equally into four experimental groups, each consisting of six rats: control (corn oil), SUM $\left(85 \mathrm{mg} / \mathrm{kg}, 1 / 20 \mathrm{LD}_{50}\right.$ [26]), HPPJ (a mixture of $22.5 \mathrm{~g}$ of citrus bee honey, $1 \mathrm{~g}$ of refined propolis, $1 \mathrm{~g}$ of palm pollen grains, and $0.5 \mathrm{~g}$ of fresh royal jelly), and SUM-HPPJ. The rats were orally treated with $1 \mathrm{~mL}$ of each treatment for 28 successive days. On the second day of the last therapy, all rats were euthanized using an anesthesia system containing diethyl ether, and blood samples were gathered from the carotid artery. All animals were treated in compliance with the standard guidelines for the laboratory animal care and use protocol of the National Research Council [27].

\subsection{Hematological Parameters}

Blood samples were gently collected in anticoagulant-containing sterilized tubes (EDTA) to provide a final concentration of $5 \mathrm{mg} / \mathrm{mL}$ blood. Samples were mixed gently and discarded if any difficulties were encountered during sampling or if clots were seen in the vial. A Sysmex KX-21 hematological analyzer (Sysmex KX21, Japan) was used to evaluate the total red blood cell (RBC) count $\left(\times 10^{6} / \mu \mathrm{L}\right)$, hemoglobin $(\mathrm{Hb})$ content $(\mathrm{g} / \mathrm{dL})$, hematocrit $(\mathrm{HCT})$ value $(\%)$, mean cell hemoglobin $(\mathrm{MCH}$; $\mathrm{pg})$, mean corpuscular volume (MCV, fL), mean corpuscular hemoglobin concentration (MCHC) values $(\mathrm{g} / \mathrm{dL})$, total white blood cell $(\mathrm{WBC})$ count $\left(\times 10^{3} / \mu \mathrm{L}\right)$, and platelet $(\mathrm{PLT})$ count $\left(\times 10^{3} / \mu \mathrm{L}\right)$ in a certified clinical laboratory.

\subsection{Enzymatic and Biochemical Parameters}

Another set of blood samples was obtained in non-anticoagulant test tubes, allowed coagulation for $15 \mathrm{~min}$ at room temperature. Subsequently, they were centrifuged for serum separation for $10 \mathrm{~min}$ at $4000 \mathrm{rpm}$ (Universal 32R, Hettich Zentrifugen model D-78532, Germany). The serum was used to examine the enzymatic and biochemical parameters. The activity of AChE was measured using the method described by Ellman et al. [28]. Blood glucose [29], uric acid [30], alkaline phosphatase (ALP) [31], total protein [32], glutathione peroxidase (GP) [33], total lipids [34], creatinine [35], glutathione-S-transferase (GST) [36], and superoxide dismutase (SOD) [37] were analyzed using BioDiagnostic kits (Diagnostic research and Reagents, Giza, Egypt). The lactate dehydrogenase (LDH) activity [38] was determined using a BioSystems Kit (BioSystems S.A., Costa Brava, Barcelona, Spain). The determination of the $\gamma$-Glutamyltransferase $(\gamma-\mathrm{GT})$ activity was done using a Spectrum Kit (MDSS, $\mathrm{GmbH}$, Schiffgraben, Germany) [39]. Each sample consisted of five replicates, and each replicate was measured three times.

\subsection{GC-MS Analysis of the HPPJ Mixture}

Approximately $2 \mathrm{~g}$ of HPPJ mixture was soaked overnight in $10 \mathrm{~mL}$ of double-distilled water. Two milliliters of the extract were then filtered using a $0.2 \mu \mathrm{m}$ PTFE filter (Fisher Scientific, Ottawa, Canada) and a $1 \mathrm{~mL}$ syringe to a $1.5 \mathrm{~mL}$ dark high-performance liquid chromatography (HPLC) glass vial. One $\mu \mathrm{L}$ of the sample was injected into an Agilent 6890 Gas Chromatography-Mass Spectrometry (GC-MS) system supplied with an Agilent mass spectrometric detector with a direct capillary interface and HP-5 capillary column $(30 \mathrm{~m} \times 0.250 \mathrm{~mm} \times 0.25 \mu \mathrm{m}$ film thickness, part No. 19091J-433). Helium was used as the carrier gas at a $1 \mathrm{~mL} / \mathrm{min}$ flow rate and $3 \mathrm{~min}$ as a solvent delay time. The mass spectrophotometric detector was performed in a state of electron impact ionization, with $70 \mathrm{eV}$ energy, 50 to $800 \mathrm{mass} / \mathrm{charge}(\mathrm{m} / \mathrm{z})$ scanning state, and at $150{ }^{\circ} \mathrm{C}$ and $230^{\circ} \mathrm{C}$ as the quadrupole and ion source temperature, respectively. The voltage of electron multipliers (EM voltage) was held at $1250 \mathrm{~V}$ above the auto-tune. Perfluorotributylamine (PFTBA) was used to manually tune the instrument. The GC temperature system was started for $3 \mathrm{~min}$ at $50{ }^{\circ} \mathrm{C}$, then increased to $280{ }^{\circ} \mathrm{C}$ at a rate of $8{ }^{\circ} \mathrm{C} / \mathrm{min}$ 
and kept for $10 \mathrm{~min}$. The recorded $\mathrm{m} / \mathrm{z}$ ratio is the fingerprint of each molecule. Additionally, the separated peaks were identified using the Wiley9 and NIST14 mass spectral database. Then, the detected compounds were individually re-confirmed via online chemical databases including AMDIS, PubChem, ChemSpider, and the Chinese Chemical database.

\subsection{Statistical Analysis}

The general linear model (GLM) procedure of the Statistical Analysis System (SAS) (Version 9.3, Cary, NC, USA, 2016) was used to examine the toxicological data. Turkey's post-hoc multiple comparison tests $(P \leq 0.05)[40]$ were used to compare significant means.

\section{Results}

\subsection{Mortality and Relative Organ Weight}

No mortality was recorded among the tested animals. The relative organ weights of the kidney, liver, heart, brain, spleen, testes, and lung were presented in Table 1. The SUM-treated rats showed significantly increased brain, kidney, and liver relative weights in contrast to the control group but did not vary remarkably from the group of rats that received SUM-HPPJ. Meanwhile, the SUM treatment did not affect the relative weight of the testes while it was decreased in rats that received SUM-HPPJ. Both the control and HPPJ treatments showed similar weights.

Table 1. The mean relative organ weights \pm SE of the liver, lung, kidney, heart, brain, spleen, lung, and testes of white albino rats who were orally administered corn oil (Control), sumithion (SUM; 85 $\mathrm{mg} / \mathrm{kg}, 1 / 20 \mathrm{LD}_{50}$ ), HPPJ (a mixture of citrus bee honey, propolis, palm pollen grains, and royal jelly), and SUM-HPPJ for 28 consecutive days.

\begin{tabular}{cccccccc}
\hline Group & Liver \pm SE & Kidney \pm SE & Heart \pm SE & Brain \pm SE & Spleen \pm SE & Lung \pm SE & Testes \pm SE \\
\hline Control & $3.11^{\mathrm{c}} \pm 0.105$ & $0.73^{\mathrm{bc}} \pm 0.042$ & $0.38^{\mathrm{a}} \pm 0.026$ & $0.713^{\mathrm{b}} \pm 0.036$ & $0.27^{\mathrm{a}} \pm 0.059$ & $0.73^{\mathrm{a}} \pm 0.045$ & $1.13^{\mathrm{a}} \pm 0.062$ \\
HPPJ & $3.36^{\mathrm{bc}} \pm 0.105$ & $0.60^{\mathrm{c}} \pm 0.042$ & $0.34^{\mathrm{a}} \pm 0.026$ & $0.704^{\mathrm{b}} \pm 0.032$ & $0.33^{\mathrm{a}} \pm 0.046$ & $0.64^{\mathrm{a}} \pm 0.045$ & $1.17^{\mathrm{a}} \pm 0.062$ \\
SUM & $3.64^{\mathrm{ab}} \pm 0.105$ & $0.82^{\mathrm{ab}} \pm 0.042$ & $0.40^{\mathrm{a}} \pm 0.023$ & $0.928^{\mathrm{a}} \pm 0.032$ & $0.26^{\mathrm{a}} \pm 0.046$ & $0.76^{\mathrm{a}} \pm 0.040$ & $1.06^{\mathrm{a}} \pm 0.062$ \\
SUM-HPPJ & $3.99^{\mathrm{a}} \pm 0.122$ & $0.94^{\mathrm{a}} \pm 0.042$ & $0.44^{\mathrm{a}} \pm 0.026$ & $0.932^{\mathrm{a}} \pm 0.036$ & $0.24^{\mathrm{a}} \pm 0.051$ & $0.79^{\mathrm{a}} \pm 0.045$ & $0.76^{\mathrm{b}} \pm 0.071$ \\
\hline
\end{tabular}

$\mathrm{n}=6$ rats/group, SE; standard error, means with the same superscript letter were not significantly different, $P \leq 0.05$, and relative organ weight $=($ organ weight/final body weight $) \times 100$.

\subsection{Hematological Parameters}

Our results showed a remarkable $(P \leq 0.05)$ decrease in RBCs, WBCs, and PLT counts, as well as hemoglobin (HGB), and MCHC contents, in SUM-intoxicated rats in comparison to the control (Table 2). The HPPJ- and SUM-HPPJ-treated rats showed similar HGB, MCV, MCH, and PLT results to those of the control group, although the SUM-treated rats had elevated MCV and MCH values $(P \leq 0.05)$ in relation to the other experimental groups. The HGB and MCHC contents of rats intoxicated with SUM were not substantially different from the control rats.

Table 2. Mean \pm SE values of the total white blood cell counts $\left(\mathrm{WBC} ; \times 10^{3} / \mu \mathrm{L}\right)$, total red blood cell count $\left(\mathrm{RBC} ; \times 10^{6} / \mu \mathrm{L}\right)$, hemoglobin content (HGB; g/dL), hematocrit value (HCT; \%), mean corpuscular volume $(\mathrm{MCV} ; \mathrm{fL})$, mean cell hemoglobin $(\mathrm{MCH} ; \mathrm{pg})$, mean corpuscular hemoglobin concentration $(\mathrm{MCHC} ; \mathrm{g} / \mathrm{dL})$, and platelets number $\left(\mathrm{PLT} ; \times 10^{3} / \mu \mathrm{L}\right)$ of white albino rats who were orally given corn oil (Control), sumithion (SUM; $85 \mathrm{mg} / \mathrm{kg}, 1 / 20$ LD50), HPPJ (a mixture of citrus bee honey, propolis, palm pollen grains, and royal jelly), and SUM-HPPJ for 28 consecutive days.

\begin{tabular}{ccccccccc}
\hline Group & WBC \pm SE & RBC \pm SE & HGB \pm SE & HCT \pm SE & MCV \pm SE & MCH \pm SE & MCHC \pm SE & PLT \pm SE \\
\hline Control & $11.20^{\mathrm{a}} \pm 0.285$ & $5.54^{\mathrm{ab}} \pm 0.188$ & $10.78^{\mathrm{ab}} \pm 0.198$ & $34.28^{\mathrm{a}} \pm 0.980$ & $59.47^{\mathrm{b}} \pm 2.530$ & $18.68^{\mathrm{b}} \pm 0.716$ & $31.43^{\mathrm{b}} \pm 0.428$ & $566.8^{\mathrm{a}} \pm 38.81$ \\
HPPJ & $10.33^{\mathrm{ab}} \pm 0.247$ & $6.05^{\mathrm{a}} \pm 0.146$ & $11.08^{\mathrm{a}} \pm 0.177$ & $34.24^{\mathrm{a}} \pm 0.877$ & $56.58^{\mathrm{b}} \pm 2.263$ & $18.32^{\mathrm{b}} \pm 0.640$ & $32.37^{\mathrm{ab}} \pm 0.383$ & $579.2^{\mathrm{a}} \pm 34.71$ \\
SUM & $7.73^{\mathrm{c}} \pm 0.247$ & $3.96^{\mathrm{c}} \pm 0.146$ & $9.98^{\mathrm{b}} \pm 0.198$ & $31.94^{\mathrm{a}} \pm 0.877$ & $81.10^{\mathrm{a}} \pm 2.263$ & $25.79^{\mathrm{a}} \pm 0.640$ & $31.85^{\mathrm{b}} \pm 0.383$ & $253.8^{\mathrm{b}} \pm 34.71$ \\
SUM-HPPJ & $9.87^{\mathrm{b}} \pm 0.285$ & $5.28^{\mathrm{b}} \pm 0.163$ & $10.50^{\mathrm{ab}} \pm 0.198$ & $31.25^{\mathrm{a}} \pm 0.980$ & $59.50^{\mathrm{b}} \pm 2.530$ & $20.00^{\mathrm{b}} \pm 0.716$ & $33.63^{\mathrm{a}} \pm 0.428$ & $522.5^{\mathrm{a}} \pm 38.81$ \\
\hline
\end{tabular}

Means were statistically compared using the Tukey's post-hoc multiple comparison methods at $P \leq 0.05$. Means with the same superscript letter were not significantly different. Each treatment was replicated six times, and each replicate was measured three times. 


\subsection{Serum Antioxidant Enzymes}

The results (Figure 1$)$ exhibited a remarkable $(P \leq 0.05)$ decrease in the serum GST activity $(21.09 \%)$ after rats ingested HPPJ, while the SUM treatment caused an increased GST by $9.81 \%$ in relation to the control, although the SUM-HPPJ-treated rats had a GST activity relative to that of the control animals. Likewise, the GP activity in the serum samples of the SUM-treated rats increased by $33.72 \%$ in comparison to the control one, while no variations were found between SUM-HPPJ and the control. On the other hand, the GP activity decreased by $15 \%$ after rats were given HPPJ relative to the control. For the SOD activity, the SUM and SUM-HPPJ treatments increased its activity $(73.72 \%$ and $39.64 \%$, respectively), while HPPJ revealed no difference compared to the control in the serum samples.
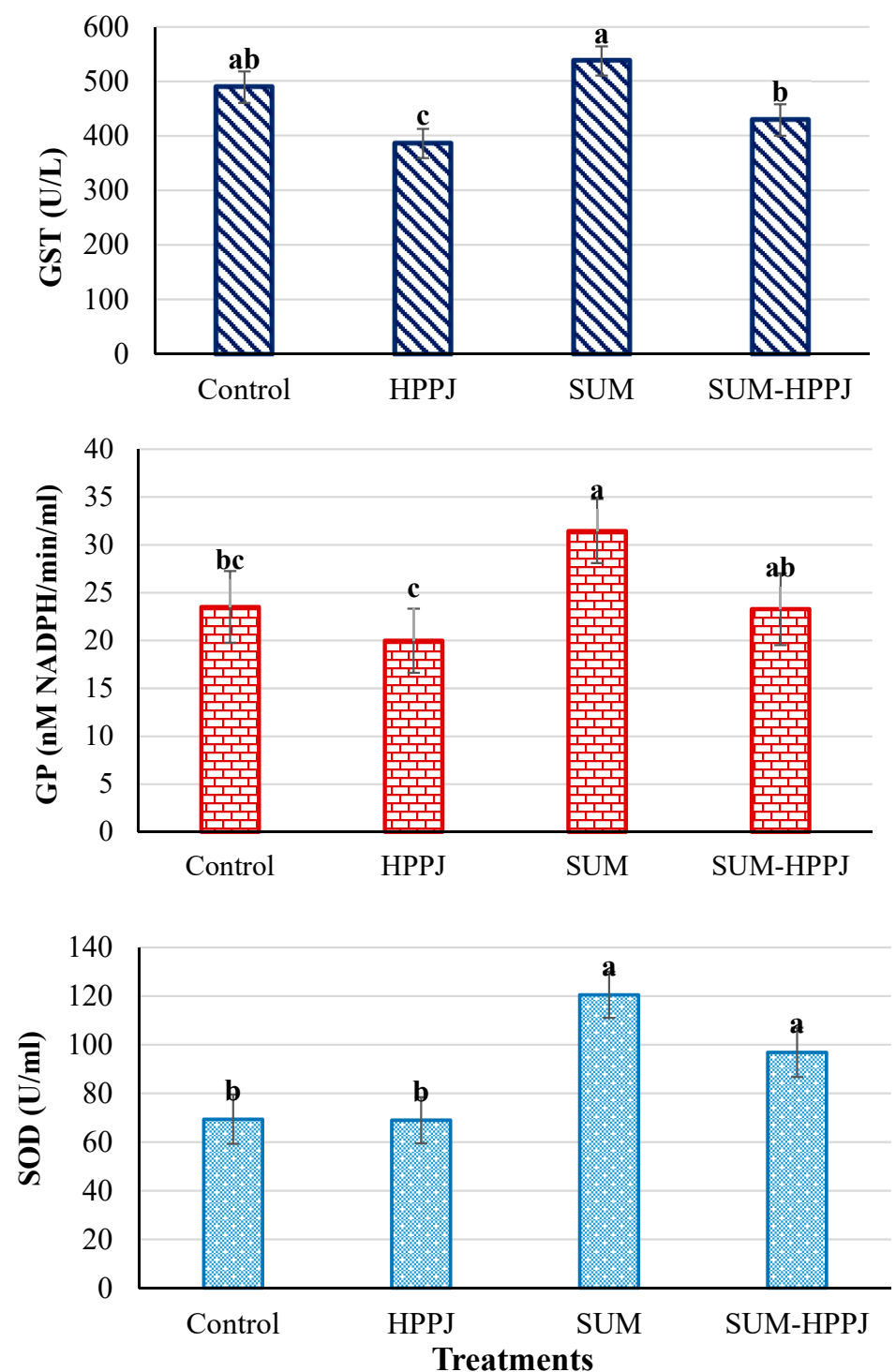

Figure 1. Mean activities of oxidative stress enzymes \pm SE: GST; glutathione-S-transferase (U/L), GP; glutathione peroxidase (nM NADPH/min/mL), and SOD; superoxide dismutase $(\mathrm{U} / \mathrm{mL})$ of white albino rats who were orally given corn oil (Control), sumithion (SUM; $85 \mathrm{mg} / \mathrm{kg}, 1 / 20$ LD 50 ), HPPJ (a mixture of citrus bee honey, propolis, palm pollen grains, and royal jelly), and SUM-HPPJ for 28 consecutive days. Columns labeled with the same small letter were not significantly different based on Tukey's post hoc specific comparison $(P<0.05)$. 


\subsection{Serum Hepatic Enzyme Activities}

In the case of SUM-treated rats, a substantial increase $(P \leq 0.05)$ was found in the activity of ALP, LDH, and $\gamma-\mathrm{GT}$ by $53.6 \%, 34.65 \%$, and $62.89 \%$, respectively, compared to the control (Figure 2). The HPPJ and SUM-HPPJ treatments did not affect the ALP activity. Meanwhile, the SUM-HPPJ treatment significantly increased the activities of both LDH $(10.45 \%)$ and $\gamma$-GT $(30.65 \%)$ compared to the control. The HPPJ treatment had no effects on any enzymes in comparison to the control.
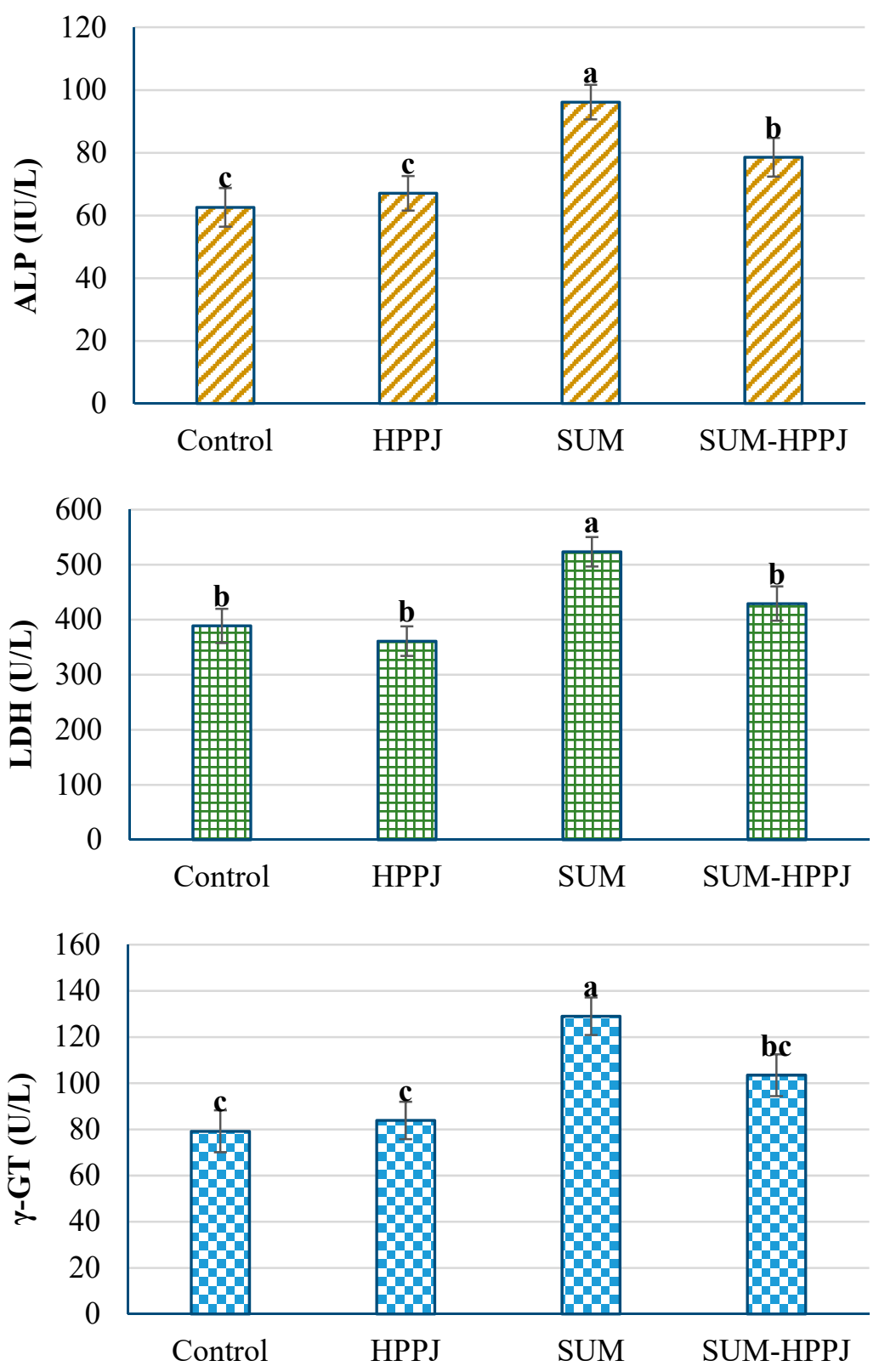

Treatments

Figure 2. Mean activities of hepatic enzymes \pm SE: ALP; alkaline phosphatase (IU/L), $\gamma$-GT; $\gamma$-glutamyl transferase $(\mathrm{U} / \mathrm{L})$, and $\mathrm{LDH}$; lactate dehydrogenase $(\mathrm{U} / \mathrm{L})$ of white albino rats who were orally given corn oil (Control), sumithion (SUM; $85 \mathrm{mg} / \mathrm{kg}, 1 / 20 \mathrm{LD}_{50}$ ), HPPJ (a mixture of citrus bee honey, propolis, palm pollen grains, and royal jelly), and SUM-HPPJ for 28 consecutive days. Columns labeled with the same small letter were not significantly different based on Tukey's post hoc specific comparison $(P<0.05)$. 


\subsection{Serum Renal and Biochemical Parameters}

The results in Table 3 disclosed that the levels of glucose, uric acid, and creatinine in SUM-treated rats increased significantly $(P \leq 0.05)$ by $27.15 \%, 57.34 \%$, and $199.85 \%$, respectively, in comparison to the control. Additionally, SUM decreased the total protein and total lipids contents and the AChE enzyme activity by about $26.53 \%, 57.57 \%$, and $37.20 \%$, respectively. However, the SUM-HPPJ-treated rats showed a reduction in the total protein, total lipids, and AChE by $13.40 \%, 27.44 \%$, and $13.42 \%$, respectively, of the control values. Creatinine increased significantly after treating the rats with SUM-HPPJ. Experimental groups treated with HPPJ showed similar values of the biochemical parameters to those of the control $(P<0.05)$, except for the protein content, which decreased.

Table 3. Mean \pm SE values of glucose $(\mathrm{mg} / \mathrm{dL})$, total protein $(\mathrm{g} / \mathrm{dL})$, total lipids $(\mathrm{mg} / \mathrm{dL})$, uric acid $(\mathrm{mg} / \mathrm{dL})$, and creatinine $(\mathrm{mg} / \mathrm{dL})$ contents and acetylcholine esterase (AChE; nM ATChI/min) activity of white albino rats who were orally given corn oil (Control), sumithion (SUM; $85 \mathrm{mg} / \mathrm{kg}, 1 / 20$ LD 50 ), HPPJ (a mixture of citrus bee honey, propolis, palm pollen grains, and royal jelly), and SUM-HPPJ for 28 consecutive days.

\begin{tabular}{ccccccc}
\hline Group & Glucose \pm SE & Total Protein \pm SE & Total Lipids \pm SE & Uric Acid \pm SE & Creatinine \pm SE & AChE \pm SE \\
\hline Control & $60.80^{\mathrm{b}} \pm 5.462$ & $7.54^{\mathrm{a}} \pm 0.477$ & $229.75^{\mathrm{a}} \pm 13.795$ & $2.93^{\mathrm{b}} \pm 0.255$ & $0.667^{\mathrm{c}} \pm 0.094$ & $20.94^{\mathrm{a}} \pm 0.662$ \\
HPPJ & $62.39^{\mathrm{b}} \pm 4.885$ & $6.60^{\mathrm{b}} \pm 0.427$ & $211.90^{\mathrm{a}} \pm 12.338$ & $3.16^{\mathrm{b}} \pm 0.228$ & $0.859^{\mathrm{c}} \pm 0.084$ & $20.23^{\mathrm{a}} \pm 0.592$ \\
SUM & $77.31^{\mathrm{a}} \pm 4.885$ & $5.54^{\mathrm{c}} \pm 0.427$ & $97.47^{\mathrm{c}} \pm 12.338$ & $4.61^{\mathrm{a}} \pm 0.228$ & $2.000^{\mathrm{a}} \pm 0.084$ & $13.15^{\mathrm{c}} \pm 0.592$ \\
SUM-HPPJ & $67.50^{\mathrm{b}} \pm 5.462$ & $6.53^{\mathrm{b}} \pm 0.477$ & $166.71^{\mathrm{b}} \pm 13.795$ & $3.91^{\mathrm{ab}} \pm 0.255$ & $1.078^{\mathrm{b}} \pm 0.094$ & $18.13^{\mathrm{b}} \pm 0.662$ \\
\hline
\end{tabular}

Means were statistically compared using the Tukey's post-hoc multiple comparison methods at $P \leq 0.05$. Means with the same superscript letter were not significantly different. Each treatment was replicated six times, and each replicate was measured three times.

\subsection{Chemical Composition of HPPJ Mixture}

The HPPJ mixture was differentiated semi-quantitatively using a calculation based on chemical databases into its main chemical components using the GC-MS (Table 4). The results revealed the identification of more than $85 \%$ of the components of the HPPJ mixture as sugars, glycosides, alcohols, aldehydes, ketones, alkanes, and fatty acids. The 5-(hydroxymethyl)-furfural (HMF) was the main constituent (24.47\%), followed by methyl-2-methyl-1,3-oxothiolan-2-yl-ketone (12.84\%), linoleic acid (10.19\%), 4H-pyran-4-one (8.57\%), 4-hydroxy-3-methyl-2-butanone-1-propanol-1-D1 $(5.59 \%)$, and triulose $(4.32 \%)$. Furthermore, the mixture had $\alpha$-d-mannofuranoside $(2.81 \%)$, D-mannitol (2.28\%), 2-hydroxy-2-cyclopenten-1-one (1.95\%), glyceraldehyde (1.73\%), propane, 1-isothiocyanato-4H-pyran-4-one $(1.21 \%)$, 5-hydroxy-7-methoxy-flavone (1.07\%), palmitic acid $(0.79 \%)$, and D-glucitol $(0.46 \%)$. Additionally, several other lactones and fatty acids were found as minor components. 
Table 4. List and percentages of chemical components of the citrus bee honey, refined propolis, palm pollen grains, and royal jelly mixture that was analyzed using gas chromatography-mass spectrometry (GC-MS) and identified from the mass spectrum of each molecule using the Wiley9 and NIST14 mass spectral databases. Then, individually listed compounds were re-confirmed through the online databases AMDIS, PubChem, ChemSpider, and Chinese Chemical database.

\begin{tabular}{lc}
\hline Chemical Component & \% in the Extract of Total \\
\hline HMF & 24.47 \\
Ketone, methyl-2-methyl-1,3-oxothiolan-2-yl & 12.84 \\
Linoleic acid (9,12-Octadecadienoic acid) & 10.19 \\
4H-Pyran-4-one & 8.57 \\
4-Hydroxy-3-methyl-2-butanone1-Propanol-1-D1 & 5.59 \\
Triulose & 4.32 \\
$\alpha$-d-Mannofuranoside & 2.81 \\
N1, N1-Dimethyl-N2-n-butylformamidine & 2.58 \\
D-Mannitol & 2.28 \\
2-Hydroxy-2-cyclopenten-1-one & 1.95 \\
Glyceraldehyde & 1.73 \\
Propane, 1-isothiocyanato-4H-pyran-4-one & 1.21 \\
Lanosta-7,9(11)-diene-3, beta-18,20-triol-3,18-diacetate & 1.16 \\
Flavone, 5-hydroxy-7-methoxy & 1.07 \\
Distannoxane, hexabutyl & 0.86 \\
Palmitic acid & 0.79 \\
D-Glucitol & 0.46 \\
$\alpha$-D-Galactopyranose & 0.44 \\
d-Glycero-d-heptose & 0.29 \\
3-Deoxy-d-mannoic lactone & 0.28 \\
2,5-Dihydroxy-3,6-dimethylhydroxy-1,4-dioxane & 0.18 \\
Heptadecanoic acid & 0.13 \\
\hline
\end{tabular}

\section{Discussion}

This study showed that bee products alleviated the toxicity of the organophosphorus pesticide SUM $\left(1 / 20 \mathrm{LD}_{50}\right)$ in the blood, liver, and kidneys of white albino rats. It is well documented that the consumption of honey and other important bee products including royal jelly, pollen, propolis, and beebread would be valuable therapeutics [41,42]. The chemical constituents of these products are responsible for its therapeutic properties [43]. Furthermore, the inflammatory effect of SUM on organs' weight leads to an increase in lung, liver, kidney, and heart weights, which was involved in significant injuries. Superoxide, peroxyl, hydroxyl, alcohol, hydroperoxyl, and alkoxyl radicals are the most common oxidative substances in the body, commonly referred to as ROS, created by gradual oxygen reduction and unpaired electrons that cause oxidative stress [44]. The OPs are oxidants that hinder the enzymatic antioxidant defenses such as catalase (CAT), SOD, GST, and GP [45-49]. On the other hand, previous research found that honey elevated the antioxidant status and resulted in a remarkable increase in the levels of packed cell volume (PCV), iron, and HGB $[21,50]$ due to it containing phenolic acids, flavonoids, Maillard reaction products, sugars, proteins, organic acids, amino acids, and other minor compounds, which could participate in its antioxidant activity [23].

The existing study showed that SUM administration resulted in a preliminary rise in antioxidant defense mechanisms, as shown by an increase in the activity of GST and SOD enzymes. This indicated that the rats were trying to counter SUM-induced oxidative stress that caused an apparent state of oxidative stress, while the SUM group of rats that received HPPJ showed significant protection, which was indicated by the increase in the SOD, GP, and GST enzyme activity. The development of ROS and reactive intermediates following OP pesticides exposure would initiate hepatotoxicity [48,51], which causes huge damage to liver cells and function such as steatosis, chronic hepatitis, aging, inflammatory damage, and ischemic injuries $[10,52,53]$. The results reported herein showed that SUM affected the hepatocellular integrity. SUM induced a marked increase in serum $\gamma$-GT, LDH, and ALP. Such a rise in 
liver enzymes may result from hepatocellular injury and impairment in cell membranes' permeability, resulting in the leakage of these enzymes into the bloodstream [54-56]. Similar findings were reported in other experiments, according to which fenitrothion has increased liver enzymes' activity in rats [45]. The rise in ALP in SUM-treated rats may be a response to improve ALP dephosphorylation in order for additional insecticide metabolism to be excreted with bile or because of deformities in the excretion of ALP in bile by hepatocytes [57].

Honey and other bee products exhibit antioxidant activities and protective effects on the damaged liver. The HPPJ mixture caused a substantial reduction in serum ALP and $\gamma$-GT, indicating a hepatoprotective efficacy. Similar to what was reported in the current study, previous studies showed that honey has an antioxidant and hepatoprotective activity that minimizes liver damage in treated rats [58]. Additionally, injured hepatocytes lead to a decrease in the hepatic capacity to synthesize proteins [59]. Our study exhibited a substantial reduction in the total protein content in the case of rats treated with SUM in comparison to the control group, which coincides with Mossa et al. [60], who showed a reduction in the albumin content after OPs exposure, resulting from the failure in liver functions [61] and metabolism [62]. Moreover, prolonged exposure to organophosphorus pesticides causes kidney failures [63] such as chlorfenvinfos, fenitrothion, and dimethoate in rats [64]. SUM (fenitrothion) showed a decrease in creatinine clearance that could be attributed to renal damage and/or other mechanisms. Our study revealed that SUM led to an increase in serum uric acid and creatinine related to rats that received SUM-HPPJ and the control group, suggesting a kidney functional dysfunction. Our findings are consistent with other reports that confirmed that the kidney was one of the OPs target organs $[47,65]$. Honey has been shown to improve renal function in normal people by elevating nitric oxide levels and reducing prostaglandins [66]. Furthermore, bee pollen and honey might exert antioxidant properties and play a beneficial role in kidney function [42].

The primary effect of SUM on the exposed organisms' nervous system is the inhibition of the AChE enzyme and an increase in the levels of acetylcholine in the cholinergic synapse. Therefore, the inhibition of butyrylcholinesterase (BuChE) and AChE is a widely known index of OPs intoxication [67,68]. In parallel with the results of the current study, cholinesterases activity inhibition may be attributed to a direct effect of fenitrothion [69] or hyperammonemia's indirect influence, and/or a synthetic decrease in liver function due to hepatopathy [70]. Serum cholinesterases are probably produced in hepatic cells, but other organs also participate in the pool of these enzymes in plasma [71]. Thus, serum AChE activity could be a liver function indicator, and decreased enzyme activity was recorded in several liver disorders such as cirrhosis and jaundice [72,73]. However, a minimal association is recorded between organ damage and the degree of AChE inhibition induced by malathion [74,75]. Additionally, our study indicated that SUM exposure was followed by a decline in the hemoglobin level, and these findings followed those shown by Mongi et al. [76], who stated that exposure to OPs affected the hematological parameters in rats. The drop in the level of hemoglobin might be attributed to an impairment of heme biosynthesis in bone marrow [65] or might be due to OPs binding to iron, accompanied by the absence of an iron combination in hemoglobin [77]. Additionally, the current study showed decreases in the HGB concentration, platelets, RBCs, and WBCs numbers in the case of SUM-treated rats, while a portion of bee bread produced a substantial increase in the HGB, iron level, and PCV in a normal individual [21]. Similar to the ameliorative effects of the HPPJ mixture, bee propolis uses standardized PCV\%, MCV, MCH, MCHC, and RBCs when used with SUM [78].

The liver is involved in the synthesis, metabolism, and transportation of lipid, as well as in impairments in the levels of plasma lipid, which may act as a simple indicator for evaluating liver dysfunctions [65]. Much research has documented changes in liver lipid profiles caused by OPs. These changes in the lipid profile may be due to fenitrothion's effect on the hepatocyte cell membrane permeability or the bile duct blockage that decreases or prevents the secretion of cholesterol into the duodenum [45]. This may also result in the enhanced hepatic synthesis and/or decreased hepatic degradation of lipids because of a decrease in the activity of lipoprotein lipase [79]. Nagaraju et al. [48] documented dyslipidemia in rats subjected chronically to monocrotophos. Fenitrothion 
sub-lethal levels reversibly boosted triglycerides in mice after 90 days of exposure [53]. The current findings revealed that administering fenitrothion induced homeostasis of glucose, as confirmed by a substantial gradual rise in the blood glucose level. Furthermore, previous research suggested that repeated exposure to OPs causes hyperglycemia and glycogen depletion in the muscle and liver $[48,65]$. This may be due to the impaired transport of glucose and the synthesis of glycogen [80]. Besides, elevated blood glucose levels can result from an imbalance between hepatic glucose output and peripheral glucose uptake [81], or as a result of an unexpectedly increased catabolism to meet higher energy requirements caused by OPs [82]. Animal studies indicate that glycogen phosphorylase activity, an enzyme that splits glycogen into glucose and decreases the hepatic glycogen content, improves following exposure to fenitrothion and malathion $[53,83]$. This was confirmed by the reduction in the concentration of hepatic glycogen after SUM exposure in fish [84]. Honey and bee products have demonstrated antidiabetic effects from animal models to clinical studies [21,85]. Correspondingly, the HPPJ-treated rats displayed a substantial reduction in glucose levels compared to control and rats treated with SUM. Researchers addressed this as a possible antidiabetic agent, and this effect is related to the existence of fructose [86]. Another possible mechanism illustrates the hypoglycemic effect of honey through the modulation of the insulin signaling pathway [87].

The protective activity of this novel medicinal recipe of honey and bee products used in the current study was not reported elsewhere (to the best of our knowledge) and might be due to its content of sugars, glycosides, alcohols, aldehydes, ketones, alkanes, and fatty acids. The HMF attenuated liver damage (fibrosis) after $\mathrm{CCl}_{4}$ [88] and alcohol-induced liver damage [89], and functioned as a cardioprotective agent [90]. Furthermore, the various components of ketones, linoleic acid, 4H-pyran-4-one, triulose, $\alpha$-d-mannofuranoside, D-mannitol, 2-hydroxy-2-cyclopenten-1-one, glyceraldehyde, propane, 1-isothiocyanato-4H-pyran-4-one, 5-hydroxy-7-methoxy-flavone, palmitic acid, and D-glucitol were reported as having antioxidant activity $[19,23,50,91]$.

\section{Conclusions}

Our findings indicate that SUM caused remarkable damage to the kidney and liver, resulting in imbalances in their functions. Strikingly, the liver was the first organ affected by SUM uptake and may delayed the impact of SUM on the kidney due to pharmacokinetic conditions or to deficiencies in hepatic production of essential proteins, which allowed the weakened liver to affect other organs. It also caused harmful ROS production which produced oxidative stress. Oxidative stress conditions affected the weights of the kidney, body, and liver and changed their biochemical indicators. The present study was motivated by the possible health benefits of bee products including royal jelly, honey, and propolis, in addition to palm pollen grains. These products are extremely abundant in active ingredients, including phenolic compounds, phenolic acid, flavonoids, enzymes, and terpenes, which have biological roles in preventing several disorders and promoting good health. The present study revealed the preventive effect of honey and other bee products against liver injury, and a synergistic effect may be considered. The mechanism of action may be linked to the bee product's antioxidant and anti-inflammatory function.

Author Contributions: Conceptualization, A.M.K.N., Y.M.M.S., and K.S.A.E.; methodology, A.M.K.N., and Y.M.M.S.; software, A.M.K.N., H.M.S., and G.E.-S.B.; validation and formal analysis, A.M.K.N., H.M.S., and G.E.-S.B.; investigation, K.S.A.E., H.M.S., and G.E.-S.B.; data curation, A.M.K.N., Y.M.M.S., K.A.E., H.M.S., and G.E.-S.B.; writing—original draft preparation, A.M.K.N., and Y.M.M.S; writing-review and editing, A.M.K.N., H.M.S., and G.E.B; visualization, A.M.K.N., Y.M.M.S, K.S.A.E., H.M.S., A.A.S., H.F.H., A.E., and G.E.-S.B.; supervision, K.S.A.E., H.M.S., G.E.-S.B., and A.M.K.N.; funding acquisition, A.A.S., H.F.H., A.E. and A.M.K.N. All authors have read and agreed to the published version of the manuscript.

Funding: Authors have no funds to report.

Acknowledgments: The authors would like to thank the staff of Pesticides Residues Analysis and Toxicity Laboratory, Faculty of Agriculture, Damanhour University for conducting the chemical (GC-MS), and toxicological assays.

Conflicts of Interest: The authors declare that they have no competing interests. 


\section{References}

1. Bao, L.-J.; Wei, Y.-L.; Yao, Y.; Ruan, Q.-Q.; Zeng, E.Y. Global trends of research on emerging contaminants in the environment and humans: A literature assimilation. Environ. Sci. Pollut. Res. 2015, 22, 1635-1643. [CrossRef] [PubMed]

2. Gavrilescu, M.; Demnerová, K.; Aamand, J.; Agathos, S.; Fava, F. Emerging pollutants in the environment: Present and future challenges in biomonitoring, ecological risks and bioremediation. New Biotechnol. 2015, 32, 147-156. [CrossRef] [PubMed]

3. Rekha, R.S.; Hamid, S. Histopathological effects of pesticide-cholopyrifos on kidney in albino rats. Int. J. Res. Med. Sci. 2013, 1, 465-475. [CrossRef]

4. Hernández, A.F.; Parrón, T.; Tsatsakis, A.M.; Requena, M.; Alarcón, R.; López-Guarnido, O. Toxic effects of pesticide mixtures at a molecular level: Their relevance to human health. Toxicology 2013, 307, 136-145. [CrossRef]

5. El-Demerdash, F.M. Lipid peroxidation, oxidative stress and acetylcholinesterase in rat brain exposed to organophosphate and pyrethroid insecticides. Food Chem. Toxicol. 2011, 49, 1346-1352. [CrossRef]

6. Afshar, S.; Farshid, A.; Heidari, R.; Ilkhanipour, M. Histopathological changes in the liver and kidney tissues of Wistar albino rat exposed to fenitrothion. Toxicol. Ind. Health 2008, 24, 581-586. [CrossRef]

7. Želježić, D.; Mladinić, M.; Žunec, S.; Vrdoljak, A.L.; Kašuba, V.; Tariba, B.; Živković, T.; Marjanović, A.; Pavičić, I.; Milić, M.; et al. Cytotoxic, genotoxic and biochemical markers of insecticide toxicity evaluated in human peripheral blood lymphocytes and an HepG2 cell line. Food Chem. Toxicol. 2016, 96, 90-106. [CrossRef]

8. Lee, J.E.; Lim, M.S.; Park, J.H.; Park, C.H.; Koh, H.C. Nuclear NF-кB contributes to chlorpyrifos-induced apoptosis through p53 signaling in human neural precursor cells. Neurotoxicology 2014, 42, 58-70. [CrossRef]

9. Vanova, N.; Pejchal, J.; Herman, D.; Dlabkova, A.; Jun, D. Oxidative stress in organophosphate poisoning: Role of standard antidotal therapy. J. Appl. Toxicol. 2018, 38, 1058-1070. [CrossRef]

10. Kumar, S.V.; Fareedullah, M.D.; Sudhakar, Y.; Venkateswarlu, B.; Kumar, E.A. Current review on organophosphorus poisoning. Arch. Appl. Sci. Res. 2010, 2, 199-215.

11. Orabi, S.H.; Elbialy, B.E.; Shawky, S.M. Ameliorating and hypoglycemic effects of zinc against acute hepatotoxic effect of chlorpyrifos. Sigma 2013, 4, 2.

12. Durak, D.; Uzun, F.G.; Kalender, S.; Ogutcu, A.; Uzunhisarcikli, M.; Kalender, Y. Malathion-induced oxidative stress in human erythrocytes and the protective effect of vitamins $\mathrm{C}$ and $\mathrm{E}$ in vitro. Environ. Toxicol. Int. J. 2009, 24, 235-242. [CrossRef] [PubMed]

13. Koehn, F.E.; Carter, G.T. The evolving role of natural products in drug discovery. Nat. Rev. Drug Discov. 2005, 4, 206-220. [CrossRef]

14. Othman, N.H. Does Honey Have the Characteristics of Natural Cancer Vaccine? J. Tradit. Complement. Med. 2012, 2, 276-283. [CrossRef]

15. Othman, N.H. Honey and Cancer: Sustainable Inverse Relationship Particularly for Developing Nations-A Review. Evid.-Based Complement. Altern. Med. 2012, 2012, 1-10. [CrossRef]

16. Ahmed, S.; Othman, N.H. Honey as a Potential Natural Anticancer Agent: A Review of Its Mechanisms. Evid.-Based Complement. Altern. Med. 2013, 2013, 1-7. [CrossRef] [PubMed]

17. Scepankova, H.; Saraiva, J.A.; Estevinho, L.M. Honey Health Benefits and Uses in Medicine. In Bee Products - Chemical and Biological Properties; Alvarez-Suarez, J.M., Ed.; Springer International Publishing: Cham, Switzerland, 2017; ISBN 978-3-319-59689-1.

18. Baltas, N.; Karaoglu, S.A.; Tarakci, C.; Kolayli, S. Effect of propolis in gastric disorders: Inhibition studies on the growth of Helicobacter pylori and production of its urease. J. Enzyme Inhib. Med. Chem. 2016, 31, 46-50. [CrossRef] [PubMed]

19. Denisow, B.; Denisow-Pietrzyk, M. Biological and therapeutic properties of bee pollen: A review. J. Sci. Food Agric. 2016, 96, 4303-4309. [CrossRef]

20. Hamza, R.Z.; Diab, A.E.A.A.; Abd El-Aziz, E.S.A.; Hendawy, A.A. Immunotoxic effect of (organophosphorous insecticides) (chlorpyrifos, profenofos) and possible ameliorative role of propolis and ginseng. Biosci. Biotechnol. Res. Asia 2013, 10, 645-651. [CrossRef]

21. Al-Waili, N.S. Effects of Daily Consumption of Honey Solution on Hematological Indices and Blood Levels of Minerals and Enzymes in Normal Individuals. J. Med. Food 2003, 6, 135-140. [CrossRef] 
22. Rzepecka-Stojko, A.; Stojko, J.; Kurek-Górecka, A.; Górecki, M.; Kabała-Dzik, A.; Kubina, R.; Moździerz, A.; Buszman, E. Polyphenols from Bee Pollen: Structure, Absorption, Metabolism and Biological Activity. Molecules 2015, 20, 21732-21749. [CrossRef] [PubMed]

23. Nagai, T.; Sakai, M.; Inoue, R.; Inoue, H.; Suzuki, N. Antioxidative activities of some commercially honeys, royal jelly, and propolis. Food Chem. 2001, 75, 237-240. [CrossRef]

24. Van Acker, S.A.B.E.; Van Den Berg, D.; Tromp, M.N.J.L.; Griffioen, D.H.; Van Bennekom, W.P.; Van Der Vijgh, W.J.F.; Bast, A. Structural aspects of antioxidant activity of flavonoids. Free Radic. Biol. Med. 1996, 20, 331-342. [CrossRef]

25. Al-Mamary, M.; Al-Meeri, A.; Al-Habori, M. Antioxidant activities and total phenolics of different types of honey. Nutr. Res. 2002, 22, 1041-1047. [CrossRef]

26. Tomlin, C.D.S. The Pesticide Manual. A World Compendium, 14th ed.; British Crop Protection Council: Surry, UK, 2006.

27. NRCNA. Guide for the Care and Use of Laboratory Animals, 8th ed.; All rats were handled in accordance with the standard guide for the care and use of laboratory animals, Ed.; National Research Council of the National Academics. The National Academics Press: Washington, DC, USA, 2011.

28. Ellman, G.L.; Courtney, K.D.; Andres, V.; Featherstone, R.M. A new and rapid colorimetric determination of acetylcholinesterase activity. Biochem. Pharmacol. 1961, 7, 88-95. [CrossRef]

29. Trinder, P. Determination of glucose in blood using glucose oxidase with an alternative oxygen acceptor. Ann. Clin. Biochem. 1969, 6, 24-27. [CrossRef]

30. Barham, D.; Trinder, P. An improved colour reagent for the determination of blood glucose by the oxidase system. Analyst 1972, 97, 142-145. [CrossRef]

31. Belfield, A.; Goldberg, D.M. Revised assay for serum phenyl phosphatase activity using 4-amino-antipyrine. Enzyme 1971, 12, 561-573. [CrossRef]

32. Gornall, A.G.; Bardawill, C.J.; David, M.M. Determination of serum proteins by means of the biuret reaction. J. Biol. Chem. 1949, 177, 751-766.

33. Paglia, D.E.; Valentine, W.N. Studies on the quantitative and qualitative characterization of erythrocyte glutathione peroxidase. J. Lab. Clin. Med. 1967, 70, 158-169.

34. Zöllner, N.; Kirsch, K. Colorimetric method for determination of total lipids. J. Exp. Med. 1962, 135, 545-555. [CrossRef]

35. Bartels, H.; Böhmer, M.; Heierli, C. Serum kreatininbestimmung ohne enteiweissen. Clin. Chim. Acta 1972, 37, 193-197. [CrossRef]

36. Habig, W.H.; Pabst, M.J.; Jakoby, W.B. Glutathione S-Transferases The first enzymatic step in mercapturic acid formation. J. Biol. Chem. 1974, 249, 7130-7139.

37. Nishikimi, M.; Appaji Rao, N.; Yagi, K. The occurrence of superoxide anion in the reaction of reduced phenazine methosulfate and molecular oxygen. Biochem. Biophys. Res. Commun. 1972, 46, 849-854. [CrossRef]

38. Burtis, C.; Ashwood, E.; Bruns, D.; Saunders, W. Tietz Textbook of Clinical Chemistry and Molecular Diagnostics, 4th ed.; Saunders: Philadephia, PA, USA, 2005.

39. Heersink, W.; Hafkenscheid, J.C.M.; Siepel, H.; Van der Enjongekryg, J.; Dijt, C.C.M. Temperature-converting factors for enzymes: Comparison of methods. Enzyme 1980, 25, 333-341. [CrossRef]

40. SAS Statistical Analysis System. Version 9.3; SAS Institute, Inc.: Cary, NC, USA, 2016.

41. Ramadan, M.F.; Al-Ghamdi, A. Bioactive compounds and health-promoting properties of royal jelly: A review. J. Funct. Foods 2012, 4, 39-52. [CrossRef]

42. Juszczak, L.; Florkiewicz, A.; Socha, R.; Gałkowska, D. Effect of honey supplementation with bee products on quality parameters and mineral composition. Emirates J. Food Agric. 2019, 30, 990-997.

43. Guimarães, N.S.S.; Mello, J.C.; Paiva, J.S.; Bueno, P.C.P.; Berretta, A.A.; Torquato, R.J.; Nantes, I.L.; Rodrigues, T. Baccharis dracunculifolia, the main source of green propolis, exhibits potent antioxidant activity and prevents oxidative mitochondrial damage. Food Chem. Toxicol. 2012, 50, 1091-1097. [CrossRef]

44. Phaniendra, A.; Jestadi, D.B.; Periyasamy, L. Free Radicals: Properties, Sources, Targets, and Their Implication in Various Diseases. Indian J. Clin. Biochem. 2015, 30, 11-26. [CrossRef]

45. Kalender, S.; Uzun, F.G.; Durak, D.; Demir, F.; Kalender, Y. Malathion-induced hepatotoxicity in rats: The effects of vitamins C and E. Food Chem. Toxicol. 2010, 48, 633-638. [CrossRef] 
46. Lasram, M.M.; Lamine, A.J.; Dhouib, I.B.; Bouzid, K.; Annabi, A.; Belhadjhmida, N.; Ben Ahmed, M.; El Fazaa, S.; Abdelmoula, J.; Gharbi, N. Antioxidant and anti-inflammatory effects of N-acetylcysteine against malathion-induced liver damages and immunotoxicity in rats. Life Sci. 2014, 107, 50-58. [CrossRef]

47. Mansour, S.A.; Mossa, A.-T.H. Oxidative damage, biochemical and histopathological alterations in rats exposed to chlorpyrifos and the antioxidant role of zinc. Pestic. Biochem. Physiol. 2010, 96, 14-23. [CrossRef]

48. Nagaraju, R.; Joshi, A.K.R.; Rajini, P.S. Organophosphorus insecticide, monocrotophos, possesses the propensity to induce insulin resistance in rats on chronic exposure. J. Diabetes 2015, 7, 47-59. [CrossRef] [PubMed]

49. Rizzati, V.; Briand, O.; Guillou, H.; Gamet-Payrastre, L. Effects of pesticide mixtures in human and animal models: An update of the recent literature. Chem. Biol. Interact. 2016, 254, 231-246. [CrossRef] [PubMed]

50. Ahmed, S.; Othman, N.H. Review of the medicinal effects of Tualang honey and a comparison with Manuka honey. Malays. J. Med. Sci. 2013, 20, 6-13.

51. Sahin, I.; Onbasi, K.; Sahin, H.; Karakaya, C.; Ustun, Y.; Noyan, T. The prevalence of pancreatitis in organophosphate poisonings. Hum. Exp. Toxicol. 2002, 21, 175-177. [CrossRef]

52. Jo, S.-H.; Son, M.-K.; Koh, H.-J.; Lee, S.-M.; Song, I.-H.; Kim, Y.-O.; Lee, Y.-S.; Jeong, K.-S.; Kim, W.B.; Park, J.-W.; et al. Control of Mitochondrial Redox Balance and Cellular Defense against Oxidative Damage by Mitochondrial NADP + -dependent Isocitrate Dehydrogenase. J. Biol. Chem. 2001, 276, 16168-16176. [CrossRef]

53. Karami-Mohajeri, S.; Ahmadipour, A.; Rahimi, H.-R.; Abdollahi, M. Adverse effects of organophosphorus pesticides on the liver: A brief summary of four decades of research. Arch. Ind. Hyg. Toxicol. 2017, 68, 261-275. [CrossRef]

54. Kavitha, B.T.; Shruthi, S.D.; Rai, S.P.; Ramachandra, Y.L. Phytochemical analysis and hepatoprotective properties of Tinospora cordifolia against carbon tetrachloride-induced hepatic damage in rats. J. Basic Clin. Pharm. 2011, 2, 139.

55. Hoekstra, L.T.; de Graaf, W.; Nibourg, G.A.A.; Heger, M.; Bennink, R.J.; Stieger, B.; van Gulik, T.M. Physiological and Biochemical Basis of Clinical Liver Function Tests. Ann. Surg. 2013, 257, 27-36. [CrossRef]

56. Avsarogullari, L.; Ikizceli, I.; Sungur, M.; gan Sözüer, E.; Akdur, O.; Yücei, M. Acute Amitraz Poisoning in Adults: Clinical Features, Laboratory Findings, and Management. Clin. Toxicol. 2006, 44, 19-23. [CrossRef] [PubMed]

57. Karou, S.D.; Tchacondo, T.; Ouattara, L.; Anani, K.; Savadogo, A.; Agbonon, A.; Ben Attaia, M.; de Souza, C.; Sakly, M.; Simpore, J. Antimicrobial, antiplasmodial, haemolytic and antioxidant activities of crude extracts from three selected Togolese medicinal plants. Asian Pac. J. Trop. Med. 2011, 4, 808-813. [CrossRef]

58. Wang, Y.; Li, D.; Cheng, N.; Gao, H.; Xue, X.; Cao, W.; Sun, L. Antioxidant and hepatoprotective activity of vitex honey against paracetamol induced liver damage in mice. Food Funct. 2015, 6, 2339-2349. [CrossRef] [PubMed]

59. Anusha, M.; Venkateswarlu, M.; Prabhakaran, V.; Taj, S.S.; Kumari, B.P.; Ranganayakulu, D. Hepatoprotective activity of aqueous extract of Portulaca oleracea in combination with lycopene in rats. Indian J. Pharmacol. 2011, 43, 563-567. [CrossRef] [PubMed]

60. Mossa, A.-T.H.; Refaie, A.A.; Ramadan, A. Effect of Exposure to Mixture of Four Organophosphate Insecticides. Res. J. Environ. Toxicol. 2011, 5, 323-335. [CrossRef]

61. Carter, C.J. Glutamine, glutamine synthetase and Huntington's disease. Lancet 1981, 317, 1427-1428. [CrossRef]

62. Tuchscherer, M.; Otten, W.; Kanitz, E.; Gräbner, M.; Tuchscherer, A.; Bellmann, O.; Rehfeldt, C.; Metges, C.C. Effects of inadequate maternal dietary protein: Carbohydrate ratios during pregnancy on offspring immunity in pigs. BMC Vet. Res. 2012, 8, 232. [CrossRef]

63. Attia, A.M.; Nasr, H.M. Dimethoate-induced changes in biochemical parameters of experimental rat serum and its neutralization by black seed (Nigella sativa L.) oil. Slovak J. Anim. Sci. 2009, 42, 87-94.

64. Kamath, V.; Rajini, P.S. Altered glucose homeostasis and oxidative impairment in pancreas of rats subjected to dimethoate intoxication. Toxicology 2007, 231, 137-146. [CrossRef]

65. Abdel-Ghany, R.; Mohammed, E.; Anis, S.; Barakat, W. Impact of Exposure to Fenitrothion on Vital Organs in Rats. J. Toxicol. 2016, 2016, 1-18. [CrossRef] 
66. Nowroozi, M.R.; Ayati, M.; Amini, E.; Radkhah, K.; Jamshidian, H.; Delpazir, A.; Ghasemi, F.; Kanafi, A.R. Assessment of testicular perfusion prior to sperm extraction predicts success rate and decreases the number of required biopsies in patients with non-obstructive azoospermia. Int. Urol. Nephrol. 2015, 47, 53-58. [CrossRef]

67. Pohanka, M. Inhibitors of acetylcholinesterase and butyrylcholinesterase meet immunity. Int. J. Mol. Sci. 2014, 15, 9809-9825. [CrossRef]

68. Nassar, A.M.K. Acetylcholinesterase: A Universal Toxicity Biomarker. J. Agric. Environ. Sci. 2016, 15, 28.

69. Elhalwagy, M.E.; Darwish, N.S.; Shokry, D.A.; El-Aal, A.G.A.; Abd-Alrahman, S.H.; Nahas, A.-A.; Ziada, R.M. Garlic and alpha lipoic supplementation enhance the immune system of albino rats and alleviate implications of pesticides mixtures. Int. J. Clin. Exp. Med. 2015, 8, 7689-7700.

70. Pinho, A.I.; Wallau, G.L.; Nunes, M.E.M.; Leite, N.F.; Tintino, S.R.; da Cruz, L.C.; da Cunha, F.A.B.; da Costa, J.G.M.; Douglas Melo Coutinho, H.; Posser, T.; et al. Fumigant Activity of the Psidium guajava Var. Pomifera (Myrtaceae) Essential Oil in Drosophila melanogaster by Means of Oxidative Stress. Oxid. Med. Cell. Longev. 2014, 2014, 1-8. [CrossRef]

71. García-Ayllón, M.S.; Silveyra, M.X.; Candela, A.; Compañ, A.; Clària, J.; Jover, R.; Pérez-Mateo, M.; Felipo, V.; Martínez, S.; Galcerán, J. Changes in liver and plasma acetylcholinesterase in rats with cirrhosis induced by bile duct ligation. Hepatology 2006, 43, 444-453. [CrossRef]

72. Vaidya, V.K. Horizontal transfer of antimicrobial resistance by extended-spectrum $\beta$ lactamase-producing enterobacteriaceae. J. Lab. Physicians 2011, 3, 37. [CrossRef] [PubMed]

73. Burnett, $W$. An assessment of the value of serum cholinesterase as a liver function test and in the diagnosis of jaundice. Gut 1960, 1, 294-302. [CrossRef] [PubMed]

74. Soltaninejad, K.; Abdollahi, M. Current opinion on the science of organophosphate pesticides and toxic stress: A systematic review. Med. Sci. Monit. 2009, 15, RA75-RA90. [PubMed]

75. Fortunato, J.J.; Agostinho, F.R.; RÉus, G.Z.; Petronilho, F.C.; Dal-Pizzol, F.; Quevedo, J. Lipid peroxidative damage on malathion exposure in rats. Neurotox. Res. 2006, 9, 23-28. [CrossRef] [PubMed]

76. Mongi, S.; Mahfoud, M.; Amel, B.; Kamel, J.; Abdelfattah, E.F. Protective effects of vitamin C against haematological and biochemical toxicity induced by deltamethrin in male Wistar rats. Ecotoxicol. Environ. Saf. 2011, 74, 1765-1769. [CrossRef]

77. Hundekari, I.; Suryakar, A.; Rathi, D. Acute organo-phosphorus pesticide poisoning in North Karnataka, India: Oxidative damage, haemoglobin level and total leukocyte. Afr. Health Sci. 2013, 13, 129-136. [CrossRef]

78. Al-Qayim, A.J.M.; Ghali, L.; Al-Azwai, T. Comparative effects of propolis and malic acid on hematological parameters of aluminum exposed male rats. Glob. J. Biosci. Biotechnol. 2014, 3, 6-11.

79. Hassan, H.A.; Yousef, M.I. Ameliorating effect of chicory (Cichorium intybus L.)-supplemented diet against nitrosamine precursors-induced liver injury and oxidative stress in male rats. Food Chem. Toxicol. 2010, 48, 2163-2169. [CrossRef]

80. Southam, A.D.; Lange, A.; Hines, A.; Hill, E.M.; Katsu, Y.; Iguchi, T.; Tyler, C.R.; Viant, M.R. Metabolomics Reveals Target and Off-Target Toxicities of a Model Organophosphate Pesticide to Roach (Rutilus rutilus): Implications for Biomonitoring. Environ. Sci. Technol. 2011, 45, 3759-3767. [CrossRef]

81. Pakzad, M.; Fouladdel, S.; Nili-Ahmadabadi, A.; Pourkhalili, N.; Baeeri, M.; Azizi, E.; Sabzevari, O.; Ostad, S.N.; Abdollahi, M. Sublethal exposures of diazinon alters glucose homostasis in Wistar rats: Biochemical and molecular evidences of oxidative stress in adipose tissues. Pestic. Biochem. Physiol. 2013, 105, 57-61. [CrossRef] [PubMed]

82. Malekirad, A.A.; Faghih, M.; Mirabdollahi, M.; Kiani, M.; Fathi, A.; Abdollahi, M. Neurocognitive, Mental Health, and Glucose Disorders in Farmers Exposed to Organophosphorus Pesticides. Arch. Ind. Hyg. Toxicol. 2013, 64, 1-8. [CrossRef]

83. Lasram, M.M.; El-Golli, N.; Lamine, A.J.; Douib, I.B.; Bouzid, K.; Annabi, A.; El Fazaa, S.; Abdelmoula, J.; Gharbi, N. Changes in glucose metabolism and reversion of genes expression in the liver of insulin-resistant rats exposed to malathion. The protective effects of N-acetylcysteine. Gen. Comp. Endocrinol. 2015, 215, 88-97. [CrossRef]

84. Srivastava, A.K.; Mishra, J. Effects of fenthion on the blood and tissue chemistry of a teleost fish (Heteropneustes fossilis). J. Comp. Pathol. 1983, 93, 27-31. [CrossRef] 
85. Omotayo, E.O.; Gurtu, S.; Sulaiman, S.A.; Wahab, M.S.A.; Sirajudeen, K.N.S.; Salleh, M.S.M. Hypoglycemic and antioxidant effects of honey supplementation in streptozotocin-induced diabetic rats. Int. J. Vitam. Nutr. Res. 2010, 80, 74. [CrossRef]

86. Erejuwa, O.O.; Sulaiman, S.A.; Wahab, M.S.; Sirajudeen, K.N.S.; Salleh, M.S.M.D.; Gurtu, S. Antioxidant protection of Malaysian tualang honey in pancreas of normal and streptozotocin-induced diabetic rats. In Proceedings of the Annales d'endocrinologie; Elsevier: New York, NY, YSA, 2010; Volume 71, pp. 291-296.

87. Batumalaie, K.; Zaman Safi, S.; Mohd Yusof, K.; Shah Ismail, I.; Devi Sekaran, S.; Qvist, R. Effect of Gelam Honey on the Oxidative Stress-Induced Signaling Pathways in Pancreatic Hamster Cells. Int. J. Endocrinol. 2013, 2013, 1-10. [CrossRef]

88. Han, X.Y.; Hu, J.N.; Wang, Z.; Wei, S.N.; Zheng, S.W.; Wang, Y.P.; Li, W. 5-HMF attenuates liver fibrosis in CCL4-plus-alcohol-induced mice by suppression of oxidative stress. J. Nutr. Sci. Vitaminol. (Tokyo) 2017, 63, 35-43. [CrossRef] [PubMed]

89. Li, W.; Qu, X.N.; Han, Y.; Zheng, S.W.; Wang, J.; Wang, Y.P. Ameliorative effects of 5-hydroxymethyl-2-furfural (5-HMF) from Schisandra chinensis on alcoholic liver oxidative injury in mice. Int. J. Mol. Sci. 2015, 16, 2446-2457. [CrossRef] [PubMed]

90. Russ, M.; Jauk, S.; Wintersteiger, R.; Andrä, M.; Brcic, I.; Ortner, A. Investigation of antioxidative effects of a cardioprotective solution in heart tissue. Mol. Cell. Biochem. 2019, 461, 73-80. [CrossRef] [PubMed]

91. Syed, I.; Lee, J.; Moraes-Vieira, P.M.; Donaldson, C.J.; Sontheimer, A.; Aryal, P.; Wellenstein, K.; Kolar, M.J.; Nelson, A.T.; Siegel, D.; et al. Palmitic acid hydroxystearic acids activate GPR40, which is involved in their beneficial effects on glucose homeostasis. Cell Metab. 2018, 27, 419-427. [CrossRef]

(C) 2020 by the authors. Licensee MDPI, Basel, Switzerland. This article is an open access article distributed under the terms and conditions of the Creative Commons Attribution (CC BY) license (http://creativecommons.org/licenses/by/4.0/). 